\title{
Purification of a Thermostable $\beta$-mannanase from Paenibacillus thiaminolyticus - Characterization and its Potential Use as a Detergent Additive
}

\author{
Samriti Dhawan (iD) \\ Department of Biotechnology, Goswami Ganesh Dutta Sanatan Dharma College, Chandigarh - 160 \\ 030, India.
}

\begin{abstract}
Endo-1, 4- $\beta$ - D-mannanase (EC 3.2.1.78) is a glycoside hydrolase involved in random cleavage of $\beta-1$, 4- D-manno-pyranosyl linkages within mannans and heteromannans and generates branched and linear oligosaccharides. A $\beta$-mannanase was purified from a thermotolerant bacterium Paenibacillus thiaminolyticus isolated from a soil sample. Enzyme was purified to homogeneity with specific activity of $8812 \mathrm{U} / \mathrm{mg}$ protein. Sodium dodecyl sulfate (SDS) and native poly-acryl amide gel electrophoresis indicated that the purified mannanase is a monomeric protein with a molecular mass of $38 \mathrm{kDa}$. The purified enzyme was found to be maximally active at temperature and $\mathrm{pH}$ of $60^{\circ} \mathrm{C}$ and 7.0 , respectively. It was stable at $55^{\circ} \mathrm{C}$ for $24 \mathrm{~h}$ and maintained more than $50 \%$ activity up to $3 \mathrm{~h}$ at $60^{\circ} \mathrm{C}$. The enzyme was very stable in the $\mathrm{pH}$ range of 5.0-9.0. Purified $\beta$-mannanase demonstrated high stability after 1 $\mathrm{h}$ of pre-incubation with most of the tested organic solvents. Enzyme retained significant stability in the presence of various detergent additives, commercially available detergents and dish washing liquids. The high compatibility and substantial stability in the presence of nonionic detergents and dishwashing liquids confirmed its utility as an additive to dish washing liquids and laundry detergents. Enzyme exhibited efficacious de-staining of heteromannan based stains of chocolate ice cream and salad dressing in the wash performance test for detergent application. It also exhibited anti-soil redeposition effect on cotton swatches treated with tennis court clay and heteromannans.
\end{abstract}

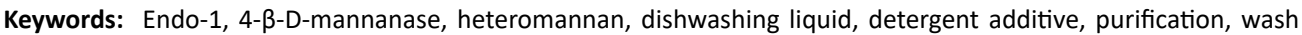
performance

*Correspondence: samriti.dhawan@ggdsd.ac.in; sdhawan_522@yahoo.com; +91-0172-4912400

(Received: August 27, 2020; accepted: February 03, 2021)

Citation: Dhawan S. Purification of a Thermostable $\beta$-mannanase from Paenibacillus Thiaminolyticus-characterization and its Potential Use as a Detergent Additive. J Pure Appl Microbiol. 2021;15(1):368-381. doi:10.22207/JPAM.15.1.31

(C) The Author(s) 2021. Open Access. This article is distributed under the terms of the Creative Commons Attribution 4.0 International License which permits unrestricted use, sharing, distribution, and reproduction in any medium, provided you give appropriate credit to the original author(s) and the source, provide a link to the Creative Commons license, and indicate if changes were made. 


\section{INTRODUCTION}

Mannans and heteromannans are natural polysaccharides existing as part of the hemicellulose fraction in plant cell walls ${ }^{1}$. Endo-1, 4- $\beta$-Dmannanase (EC 3.2.1.78) is an endohydrolase, which randomly cleaves pyranosyl linkages within the main chain of various heteromannans and mannan to release oligosaccharides of different lengths. $\beta$-mannanase production is elaborated by diverse grups of bacteria, actinomycetes, and fungi isolated from natural sources ${ }^{2}$. Although a number of mannanase-producing microbial sources are available, only a few are commercially exploited as wild or recombinant strains, of these, the important ones are: Trichoderma longibrachiatum, Aspergillus niger, Bacillus sp., thermophilic microorganisms from hydrothermal vents ${ }^{2}$. In spite of several available reports on mannolytic microorganisms, their practical potentialities were yet not fully exploited ${ }^{3}$. $\beta$-mannanase has been studied mainly with respect to their varied industrial potential ${ }^{4}$. A bacterium Paenibacillus thiaminolyticus was isolated in our laboratory and reported previously because of its rapid growth, capacity to secrete a high level of extracellular $\beta$-mannanase $(1100 \pm 50 \mathrm{U} / \mathrm{ml})$, into the growth medium and for its potential prebiotic properties ${ }^{5}$. During the course of study, on the application of enzyme, another possible use for mannanase as an additive for improving the efficacy of detergents was evaluated. Very few reports exist on detergent application studies of $\beta$-mannanase ${ }^{3,6}$. Ideally, for an enzyme to be used in detergent formulation, it should exhibit stability over a broad range of temperature and $\mathrm{pH}$. Thermal stability in the presence of detergent components such as surfactants and various detergent additives is a major prerequisite.

In the present study, thermostable $\beta$-mannanase from $P$. thiaminolyticus was purified and characterized. The efficacy of the enzyme was examined for its wide application in detergent industry. Previous studies on purification and characterization of $\beta$-mannanase had been reported from Paenibacillus sp. BME-147, Paenibacillus sp. DZ3 ${ }^{8}$, Paenibacillus sp. $\mathrm{CH}-3^{9}$, but its potential as detergent additive had not been explored.

\section{MATERIALS AND METHODS \\ Microorganism and culture conditions}

A thermotolerant bacterium Paenibacillus thiaminolyticus producing an extracellular thermostable $\beta$-mannanase isolated from a soil sample was reported earlier ${ }^{5}$. Optimized production medium used was a Mineral salt (MS) medium complemented with $2 \% \mathrm{WB}$ (wheat bran) adjusted to $\mathrm{pH}$ 7.0. The mineral salt medium was inoculated with $16 \mathrm{~h}$ seed culture ( $2 \%$ inoculum) and incubated for $48 \mathrm{~h}$ at $50^{\circ} \mathrm{C}$. The cell pellet was separated by centrifugation at $6000 \times \mathrm{g}$ for 10 minutes in a cooling centrifuge and cell-free clear supernatant was used as crude enzyme ${ }^{5}$.

\section{Materials}

Mannan (Ivory nut) and Mannooligosaccharide were acquired from Megazyme. Konjac Gluco Mannan (KGM) was obtained from TerraVita Herbs, Ontario. Various column media and columns used were procured from Pharmacia. All chemicals used were of analytical grade.

Assay for mannanase activity and protein assay

Enzyme activity was assayed using cell free clear supernatant. $\beta$-mannanase activity was assayed by the dinitrosalicylic acid (DNSA) method of Miller ${ }^{5,10}$. Protein concentration was measured by the method of microbicinchoninic acid (BCA) protein assay using a protein assay kit. BSA- bovine serum albumin was used as the standard. All column chromatographic elutes were monitored for protein content by recording absorbance at $280 \mathrm{~nm}$. All the experimental values represent the mean of three determinations carried out in duplicate. In no case did the difference between duplicates exceed $5 \%$.

\section{Purification of $\boldsymbol{\beta}$-mannanase produced by $\boldsymbol{P}$. thiaminolyticus}

$\beta$-mannanase was purified from extracellular fraction using multiple steps. The purification procedure was simplified by the presence of low amount of total protein in the extracellular fraction as compared to cell extract. To the clarified pre-chilled culture supernatant ammonium sulphate was added with constant stirring to achieve $80 \%$ saturation. The mannanase activity and the protein content were determined both in the pellet and the supernatant. $\beta$-mannanase activity was recovered in the pellet, 
pellet was resuspended in $0.05 \mathrm{M}$ potassium phosphate buffer (KPB)-pH 7.0. Mannanase fraction obtained was subjected to hydrophobic interaction chromatography. Mannanase fraction obtained was loaded on a pre equilibrated Phenyl Sepharose (Pharmacia) column $(9.0 \times 1.0 \mathrm{~cm} 2)$ with equilibration buffer. Active fractions with mannanase activity were pooled together and the volume of pooled fractions was noted. Protein concentration as well as enzyme activity was determined for the fractions. Dialyzed pooled HICfraction containing mannanase was concentrated on an Amicon ultrafiltration membrane filter with $10 \mathrm{kDa}$ cut-off. The fractions were analyzed for purity and mannanase activity 5 .

\section{SDS-PAGE and Zymogram}

Molecular weight of the purified enzyme was estimated by performing SDS-PAGE in a 12.0 $\%(\mathrm{w} / \mathrm{v})$ polyacrylamide gel. Pre-stained medium range (14.3-66 kDa) molecular weight markers were used. Coomassie brilliant blue R-250 staining was done to observe protein bands.

Zymogram was obtained by modifying the method of Blank et al. ${ }^{11}$. After electrophoresis, gel was soaked in $0.1 \%(\mathrm{v} / \mathrm{v})$ Triton-X 100 with gentle shaking to remove SDS and to renature enzymes in the gel. This washing process was repeated twice for $30 \mathrm{~min}$. Final washing was given in $100 \mathrm{mM}$ KPB ( $\mathrm{pH}$ 6.5) with gentle shaking for 15 minutes. To detect mannanase activity, gel was placed on an agarose mannan sheet ( $10 \mathrm{~mm}$ thick) that included $1 \%$ glucomannan, $1.8 \%$ agarose, and $100 \mathrm{mM}$ KPB (pH 6.5) and incubated at $55^{\circ} \mathrm{C}$ for $45 \mathrm{~min}^{12}$. The polyacrylamide gel was separated off from the mannan agarose gel sheet. Agarose gel sheet containing substrate was stained with $(0.1 \%, \mathrm{w} / \mathrm{v})$ congo red solution.

\section{Characterization of purified mannanase}

The optimal temperature for purified enzyme preparation was analysed at different temperature ranging from $37-80^{\circ} \mathrm{C}$. Purified mannanase thermal stability was assayed in temperature ranges of 55 to $80^{\circ} \mathrm{C}$. The time of incubation varied from 30 to 120 minutes. Aliquots were withdrawn periodically to assay residual enzyme activity at $\mathrm{pH} 7.0$ and at $60^{\circ} \mathrm{C}$. To determine the optimum $\mathrm{pH}$ of purified enzyme, its activity was assayed at different $\mathrm{pH}$ from (4.0-12.0) at $60^{\circ} \mathrm{C}$. For pH 4.0-12.0 (50 mM) Citrate Buffer, Phosphate Buffer, Tris-Buffer, Glycine-Sodium
Hydroxide Buffer were prepared. To test the $\mathrm{pH}$ stability, equal volume of the purified mannanase was incubated with various buffers mentioned above $(50 \mathrm{mM})$ ranging from $\mathrm{pH} 4.0-10.0$ at $55^{\circ} \mathrm{C}$ for $1 \mathrm{~h}$ to overnight. The residual enzyme activity was subsequently determined using DNS assay as described before. The unincubated sample served as control (100\% activity).

\section{Substrate specificity and kinetic analysis}

Substrate specificity of the purified mannanase was determined by incubating the enzyme with one of the following substrates $(1 \% \mathrm{w} / \mathrm{v})$ : Locust bean gum, Xylan (oat spelt), Mannan (ivory nut), Starch, Guar gum, Pectin, Chitin, Konjac glucomannan, and CM-cellulose prepared in potassium phosphate buffer $(50 \mathrm{mM})$ $\mathrm{pH}$ 7.0. Reducing sugar liberated from different polysaccharides was quantified under standard assay conditions in the reaction product.

Kinetic constants, Vmax and $\mathrm{Km}$, were determined for $\beta$-mannanase by using LineweaverBurk plot assuming that simple Michaelis-Menten kinetics was followed. The mannanase activity was calculated at its previously determined optimal $\mathrm{pH}$ and temperature. The Vmax and $K m$ for purified enzyme were evaluated by varying concentrations of the LBG $(0.1-10 \mathrm{mg} / \mathrm{ml})$ as substrate.

\section{Effect of stabilizers/ organic solvents}

The significant effect of different organic solvents ethanol, methanol, propanol, DMSO, glycerol, propanone, ethylene glycol, polyethylene glycol and isoamyl alcohol on enzyme stability was determined at $30 \%(\mathrm{v} / \mathrm{v})$ concentration. Residual $\beta$-mannanase activity was quantified by incubating purified enzyme for $60 \mathrm{~min}$ to overnight with the selected organic solvent at $55^{\circ} \mathrm{C}$.

Suitability of $\beta$-mannanase for detergent application

Effect of surfactants/detergent additives

Stability and compatibility of $P$. thiaminolyticus purified mannanase with various ionic (negatively charged-SDS and positively charged-CTAB and non-ionic detergents- Polysorbate-20 (PS-20), Polysorbate-40 (PS-40), Triton-X-100 (TX-100) were checked. $\beta$-mannanase was incubated in the detergents at $60^{\circ} \mathrm{C}$ for one hour. The stability of the mannanase in various detergent additives [builders (zeolites, sorbitol, mannitol, citric acid), bleaching agents $\left(\mathrm{H}_{2} \mathrm{O}_{2}\right.$, sodium perborate) and other components like optical brighteners 
(Polyethylene-glycol), anti-redeposition and soil suspension agent (CM-cellulose), dye tranfer inhibiting agents (Polyvinyl pyrollidone) and bulking agent (Sodium sulfate)] was investigated by incubating $0.5 \mathrm{U} / \mathrm{mL}$ mannanase with these agents $(7 \% \mathrm{w} / \mathrm{v})$ for $60 \mathrm{~min}$ at $55 \mathrm{C}$. Residual $\beta$-mannanase activity was quantified in the samples treated with different detergent additives. Enzymatic activity determined in the absence of any surfactant/ detergent additives under similar conditions was taken as control.

\section{Compatibility of mannanase with commercial detergents}

Effect of various locally available detergent powders was replicated by testing the stability of the purified mannanase in the presence of detergents powders of different compositions viz. Rin, Ariel, Wheel, Tide, Henko, Nirma, Ranipal and Ezee, and dish washing Liquids viz. Pril, Scrubz, Vim and Dettol Dish. The assay for mannanase was carried out in the presence of these washing powders/liquids, by adjusting the conc. of each detergent to $0.7 \%$ in a final volume of assay mixture, using LBG as a substrate at $60^{\circ} \mathrm{C}$. The effect of all washing powders was also checked by adjusting their $\mathrm{pH}$ to 7.0, to overcome the effect of variable $\mathrm{pH}$ of different washing powders on enzyme activity and stability.

\section{Cleaning performance test}

To check efficacy of purified mannanase as a detergent additive, multiple white cotton swatches that were stained with chocolate ice cream and salad dressing dried overnight at $37^{\circ} \mathrm{C}$ were used. To evaluate the cleaning ability of purified mannanase, stained cotton swatches were soaked in a series of flasks (from a-f), where each flask contained unfiltered tap water $(20 \mathrm{ml})$ and different combinations of detergents and detergent additives with or without enzyme $(5 \mathrm{ml})$ each of :

1. Detergent [Henko] $\left(7 \mathrm{mg} \mathrm{ml}^{-1}\right)$

2. Detergent [Henko] $\left(7 \mathrm{mg} \mathrm{ml}^{-1}\right)$ containing $1 \mathrm{U}$ $\mathrm{ml}^{-1}$ mannanase,

3. Liquid detergent [Ezee] $(1 \% \mathrm{v} / \mathrm{v})$ containing $1 U \mathrm{ml}^{-1}$ mannanase,

4. $1 \mathrm{U} \mathrm{ml}^{-1}$ mannanase.

5. TX-100 (1\%) containing $1 \mathrm{U} \mathrm{ml}^{-1}$ mannanase,

6. Homemade detergent mix containing nonionic surfactant TX-100 and all other detergent additives (sorbitol, $\mathrm{H}_{2} \mathrm{O}_{2}, \mathrm{PVP}, \mathrm{CM}$-cellulose, PEG) containing $1 \mathrm{U} \mathrm{ml}^{-1}$ mannanase.

Commercial detergents were heated at $65^{\circ} \mathrm{C}$ for $15 \mathrm{~min}$ to inactivate any inherent enzyme pre-added to detergent to avoid interference with cleaning performance.

To test anti-soil redeposition on fabric, clean cotton swatch was dipped in a set of beakers containing selected detergent mix along with tennis court clay and LBG. The solution was kept in swirling motion at $60^{\circ} \mathrm{C}$ for $15 \mathrm{~min}$ with mannanase and the cotton swatches were taken out to wash. The swatches were rinsed with water, two to three times and then allowed to dry. The cleaning performance was evaluated and compared with a set of control cotton swatches. The control swatches were swirled without adding mannanase in the detergent mix.

\section{RESULTS AND DISCUSSION \\ Protein purification and molecular weight determination}

$\beta$-mannanase was fractionated from clear culture supernatant of $P$. thiaminolyticus using salting out by $80 \%$ ammonium sulfate

Table 1. Purification of $\beta$-mannanase by ammonium sulphate, phenyl sepharose and ultrafilteration from $P$. thiaminolyticus culture filtrate

\begin{tabular}{lccccc}
\hline Purification step & $\begin{array}{c}\text { Total Enzyme } \\
\text { Activity }(\mathrm{U})\end{array}$ & $\begin{array}{c}\text { Total Protein } \\
(\mathrm{mg})\end{array}$ & $\begin{array}{c}\text { Specific activity } \\
\left(\mathrm{U} \mathrm{mg} \text { }^{-1} \text { of protein) }\right.\end{array}$ & $\begin{array}{c}\text { Yield } \\
(\%)\end{array}$ & $\begin{array}{c}\text { Fold } \\
\text { purification }\end{array}$ \\
\hline $\begin{array}{l}\text { Culture filtrate } \\
\text { Ammonium Sulphate }\end{array}$ & 52164 & 30 & 1738.8 & 100 & 1 \\
fraction (80\%) & 24957 & 4.45 & 5608.5 & 47.8 & 3.20 \\
$\begin{array}{l}\text { Phenyl Sepharose fraction } \\
10 \text { kDa cut off membrane }\end{array}$ & 13951 & 1.99 & 7011 & 26.7 & 4.03 \\
\hline
\end{tabular}

a. Activity was measured in $50 \mathrm{mM} \mathrm{KPB}(\mathrm{pH} 7.0)$ using $1.0 \%(\mathrm{w} / \mathrm{v})$ locust bean gum as substrate by the DNS method. b. The protein was measured using the method of BCA using BSA (bovine serum albumin) as the standard. 
saturation followed by hydrophobic interaction chromatography. Fig. 1 showed the elution of $\beta$-mannanase as a single peak from Phenyl Sepharose column. The purification yielded 5.06 fold enhancements in purification and specific activity was $8812 \mathrm{U} / \mathrm{mg}$ protein toward LBG (Table 1). Final yield of the purified product was calculated to be $26.7 \%$. Purified mannanase specific activity observed to be quite higher than many bacterial mannanases: 5,065 U/ mg from Bacillus sp. N16-5 $5^{13} ; 4839 \mu \mathrm{mol} / \mathrm{min} / \mathrm{mg}$ from B. subtilis ${ }^{14}$; $3,590 \mathrm{U} / \mathrm{mg}$ from $D$. thermophilum Rt46B. $1^{15}$. Though recombinant mannanases from $B$. subtilis BE- $91^{16}$ and $B$. subtilis WY $34^{17}$ demonstrated high specific activity when compared with the mannanase from $P$. thiaminolyticus. Generally highly thermostable endo- $\beta$ - 1 , 4-mannanases possess low specific activity related to their mesophilic counterparts ${ }^{16,18,19}$. However, the $P$. thiaminolyticus $\beta$-mannanase elucidated in our study is characterized by a particularly high specific activity of $8812 \mathrm{U} / \mathrm{mg}$ as well as a relatively high thermostability.

Molecular weight of the purified enzyme was calculated to be $38 \mathrm{kDa}$. The purified mannanase appeared as a single protein band, corresponding to an active band on zymogram (Fig. 2). A single band as a zone of clearance (yellow halo on a red background) appeared, thus confirming that the purified protein is a mannanase. It further confirmed that this mannanase is a monomeric protein. P. thiaminolyticus molecular mass was comparable to those of $\beta$-mannanase from Paenibacillus sp. DZ3 $(39 \mathrm{kDa})^{8}$, and less than that of several Paenibacilli sp. $(53 \mathrm{kDa}, 50.4 \mathrm{kDa})^{7,9}$.

Temperature optima and thermal stability of $\beta$-mannanase

The temperature optima for purified enzyme preparation was found to be $60{ }^{\circ} \mathrm{C}(\mathrm{pH}$ 7.0). The mannanase activity increased upto $60^{\circ} \mathrm{C}$ but with further increase in temperature it declined. Higher than $70 \%$ of the original activity was retained till $75^{\circ} \mathrm{C}$ but declined to $45 \%$ at $80^{\circ} \mathrm{C}$. An optimal temperature between $55^{\circ} \mathrm{C}$ to $70^{\circ} \mathrm{C}$ was reported from many purified mannanases from Bacillus sp. ${ }^{16,17,20,21}$.

Thermal stability of purified mannanase was assayed in temperature range of 55 to $80^{\circ} \mathrm{C}$. The enzyme showed maximum stability at $55^{\circ} \mathrm{C}$, showing no loss of mannanase activity after incubation for $2 \mathrm{~h}$. At $60^{\circ} \mathrm{C}$ and $65^{\circ} \mathrm{C}$ the enzyme retained more than $50 \%$ of its original activity after $2 \mathrm{~h}$ of incubation. At $70^{\circ} \mathrm{C}$ and $80^{\circ} \mathrm{C}$, half life was $0.38 \mathrm{~h}$ and $0.3 \mathrm{~h}$ respectively [Fig. $3 \mathrm{~b}$ ]. The residual enzyme activity demonstrated that enzyme was completely stable for $1 \mathrm{~h}$ till $60^{\circ} \mathrm{C}$.

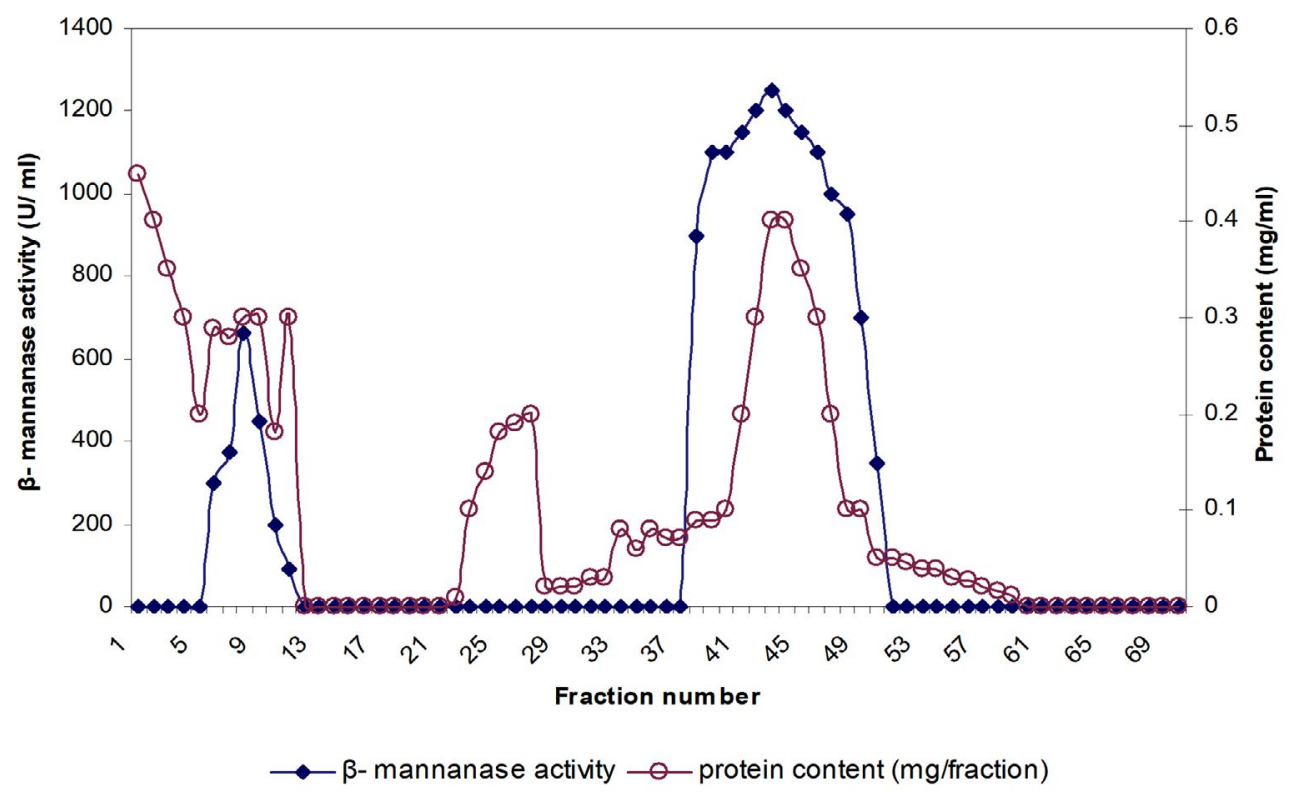

Fig. 1. Hydrophobic interaction chromatography of $\beta$-mannanase active fractions, obtained after phenyl sepharose column chromatography. Fractions were tested for protein (-o-) and $\beta$ - mannanase activity (- - -). 
At $70^{\circ} \mathrm{C}$ the percent residual activity was reduced to $30 \%$ after $1 \mathrm{~h}$ while only one tenth enzyme activity at $80^{\circ} \mathrm{C}$. Residual mannanase activities after $2 \mathrm{~h}$ at $60^{\circ} \mathrm{C}$ and $65^{\circ} \mathrm{C}$ for $P$. thiaminolyticus were $61.71 \%$ and $51.33 \%$ respectively. Mannanase revealed analogous thermo stability to the various Bacilli strains viz. Bacillus sp. SWU60 ${ }^{22}$ which is stable up to $60^{\circ} \mathrm{C}$ with $90 \%$ residual activity after 1 h. B. circulans CGMCC- 1554 was stable at $60^{\circ} \mathrm{C}$ but its activity was completely lost after $20 \mathrm{~min}$ of incubation ${ }^{14}$. P. thiaminolyticus mannanase possessing higher temperature optima and thermal stability make it a more appropriate candidate for its use in detergent industry.

Effect of $\mathrm{pH}$ on activity and stability of $\beta$-mannanase

The $\mathrm{pH}$ optimum for purified enzyme preparation was $\mathrm{pH} 7.0$ and it demonstrated $90 \%$ of maximal activity at a $\mathrm{pH}$ range from 6.0 to 7.0. Higher than $65 \%$ of the original activity was retained till $\mathrm{pH}$ 9.0, whereas enzyme inactivation was observed below $\mathrm{pH}$ 4.0. Optimum $\mathrm{pH}$ of $P$.

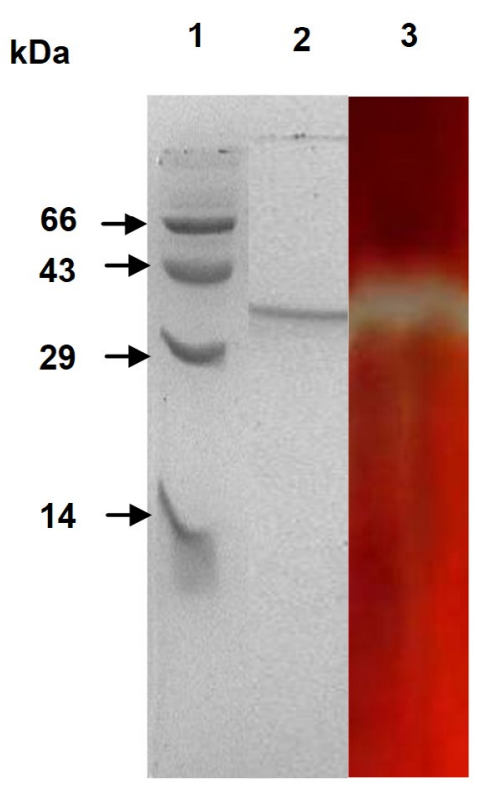

Fig. 2. Analysis of the purified enzyme by SDS-PAGE and zymography. SDS-PAGE (12\%) with Coomassie staining. Lane 1- molecular weight markers. Lane 2- The purified enzyme. Lane 3- Zymography with Konjc-glucomannan as the substrate white band indicate $\beta$-mannanase activity. thiaminolyticus mannanase was similar to $\mathrm{B}$. subtilis mannanase ${ }^{22}, B$. pumilus (6.0-7.0), $B$. circulans CGMCC 1416 (5.5-7.0) ${ }^{14}, B$. subtilis WY $34(6.5-7.5)^{17}$. Purified mannanase $\mathrm{pH}$ stability was assessed from $\mathrm{pH} 4.0$ to 10.0. The enzyme displayed maximum stability at $\mathrm{pH} 7.0$ retaining $100 \%$ of its activity even after $24 \mathrm{~h}$ (Fig. 3c). The mannanase exhibited moderate stability in the range of $\mathrm{pH}$ 6.09.0 at $60^{\circ} \mathrm{C}$ for $1 \mathrm{~h}$. Purified mannanase possessed higher stability towards slightly alkaline conditions when compared with crude enzyme extracted from $P$. thiaminolyticus ${ }^{5}$, Thus, propelling us to explore its possible application in detergents. Bacillus sp. SWU60 22 mannanase was stable at pH 5-9 at $4^{\circ} \mathrm{C}$ for 16 h. Bacillus subtilis BM 9602 also showed maximum stability in a range of $\mathrm{pH}$ 6.0-8.5 $5^{23}$ which is in agreement with mannanase from $P$. thiaminolyticus.

Substrate specificity and kinetic parameters

The activity of purified enzyme towards various substrates was determined. Relative enzyme activity was quantified by measuring the amount of liberated reducing sugars from polysaccharides (Table 2). Among Heteromannans Locust Bean Gum (LBG) released the largest quantity of reducing sugars. Konjac glucomannan (KGM) displayed related results like LBG, when LBG was substituted with Guar Gum (GG) led to approximately $70 \%$ decrease in enzyme activity. The lower activity towards guar gum was supporting the hypothesis that the mannanase activity gets affected by the degree and number of branched $\alpha$-galactose residues on the main chain of heteromannans $s^{3,6,24}$. It poorly hydrolyzed

Table 2. Substrate specificity of $\beta$-mannanase of $P$. thiaminolyticus

\begin{tabular}{lc}
\hline Polysaccharides & Relative enzyme activity (\%) \\
\hline Locust bean gum & $100 \pm 4.28$ \\
Konjak glucomannan & $98.25 \pm 5.22$ \\
Guar gum & $35.5 \pm 0.50$ \\
Mannan (INM) & $10 \pm 2.28$ \\
Starch & $72.25 \pm 4.19$ \\
Xylan & ND \\
Pectin & ND \\
CMC & ND \\
Chitin & ND
\end{tabular}

ND-Not detected. 

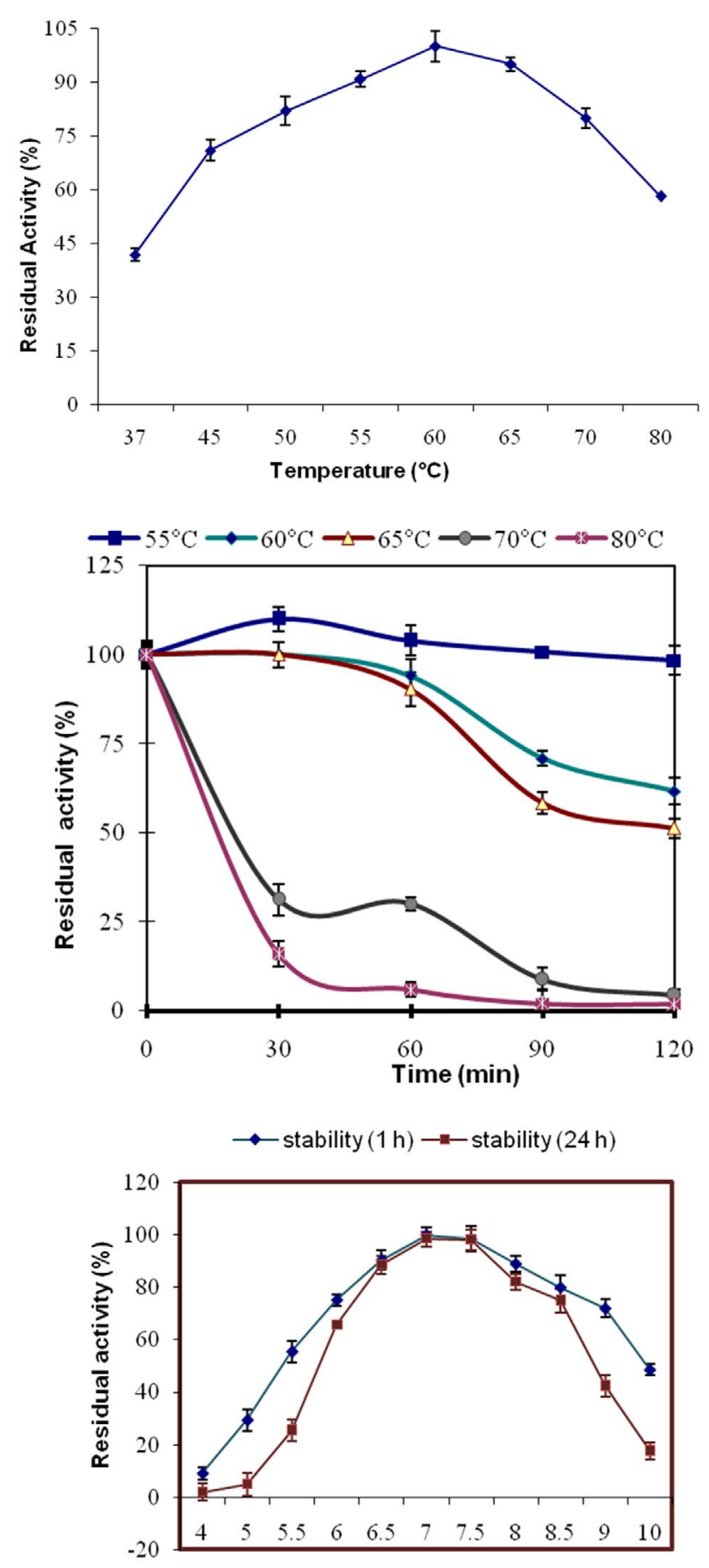

$\mathrm{pH}$

Fig. 3. (a) Effect of temperature on the activity of purified $\beta$-mannanase from $P$. thiaminolyticus. (b) Effect of temperature on thermal denaturation of $\beta$-mannanase After preincubation at $55^{\circ} \mathrm{C}$ (Squares), $60^{\circ} \mathrm{C}$ (filled diamonds), $65^{\circ} \mathrm{C}$ (filled triangles), $70^{\circ} \mathrm{C}$ (filled ovals) and $80^{\circ} \mathrm{C}$ (colored cross) for various lengths of time followed by enzyme assay at $60^{\circ} \mathrm{C} .3$ (c). Effect of $\mathrm{pH}$ on the stability of purified $\beta$-mannanase from P. thiaminolyticus. The pH stability was determined by measuring the residual activity after incubation at various $\mathrm{pH}$ values at $55^{\circ} \mathrm{C}$ for $1 \mathrm{~h}$ and $24 \mathrm{~h}$. 
unbranched $\beta-1$, 4-mannan (INM) homopolymer. This result suggested that purified mannanase is able to hydrolyze substituted mannans more effectively as substrates. Purified enzyme hydrolyzed the starch, but it was not active on either CM-cellulose, xylan or pectin, signifying that it could not cut the $\beta-1,4$-cellulosic linkages and did not have xylanolytic and pectinolytic activity.

Enzyme kinetics was studied with LBG as substrate. The kinetic parameters obtained correspond to a $V_{\max }$ of $1111.11 \mathrm{U} / \mathrm{mg}$ and a $K_{m}$ of $5 \mathrm{mg} / \mathrm{ml}$ for the $\beta$-mannanase (Fig. 4). Kinetic constant $\left(K_{m}\right)$ and the maximal reaction velocity $\left(V_{\max }\right)$ values of $\beta$-mannanases, are described for various bacteria. For $B$. subtilis SA-22 $V_{\max }-188.68$ $\mu \mathrm{mol}$ min-1 ml-1 was reported for Locust bean Gum ${ }^{25}$, Whereas, in Bacillus subtilis evident $V_{\max }$ values of the mannanase for locust bean gum, guar gum and konjac powder were $970.3 \pm 10.3$, $556.4 \pm 15.2$ and $435.3 \pm 29.1 \mu \mathrm{mol} \mathrm{min} \mathrm{m} \mathrm{ml}^{-1}$ respectively ${ }^{17}$. kinetic comparisons remained difficult in context to $\beta$-mannanase as pattern and extent of branching of polymeric chains of mannose vary with different galactomannans isolated from different sources. The lack of standardization in the substrates utilized, their method of preparation and variations in the temperature and $\mathrm{pH}$ conditions during the assay make it difficult to compare the kinetic constants of mannanases from different microorganisms. Effect of stabilizers/ organic solvents on mannanase activity and stability

The significant effect of different organic solvents ethanol, methanol, propanol, DMSO, glycerol, propanone, ethylene glycol, polyethylene glycol and iso-amyl alcohol on enzyme activity and stability was determined at $30 \%(\mathrm{v} / \mathrm{v})$ concentration. Residual $\beta$-mannanase activity revealed that Glycerol, DMSO, ethylene glycol, polyethylene glycol (PEG) had a stimulatory effect on the mannanase activity. Ethanol, methanol and

Table 3. Effect of stabilizers/ organic solvents on mannanase activity and stability

\begin{tabular}{lcc}
\hline $\begin{array}{l}\text { Organic } \\
\text { solvents } \\
30 \%(\mathrm{v} / \mathrm{v})\end{array}$ & $\begin{array}{c}\text { Residual } \\
\text { activity } \\
\text { after } 1 \mathrm{~h}\end{array}$ & $\begin{array}{c}\text { Residual } \\
\text { activity } \\
\text { after } 24 \mathrm{~h}\end{array}$ \\
\hline Control & $100 \pm 1.42$ & $100 \pm 3.25$ \\
Ethanol & $31.2 \pm 2.15$ & $11.77 \pm 1.54$ \\
Methanol & $80.92 \pm 3.44$ & $15.77 \pm 1.22$ \\
Propanol & $21.38 \pm 0.42$ & $12.01 \pm 4.15$ \\
DMSO & $121.8 \pm 1.50$ & $111.4 \pm 1.70$ \\
Glycerol & $111.15 \pm 1.00$ & $113.22 \pm 3.16$ \\
$\begin{array}{l}\text { Propanone } \\
\text { Ethylene glycol }\end{array}$ & $39.34 \pm 4.42$ & $14.07 \pm 3.42$ \\
Poly ethylene & $124.19 \pm 1.85$ & $127.66 \pm 2.65$ \\
glycol & $114.3 \pm 2.75$ & $126.09 \pm 3.18$ \\
Iso-amyl alcohol & $112.25 \pm 4.45$
\end{tabular}

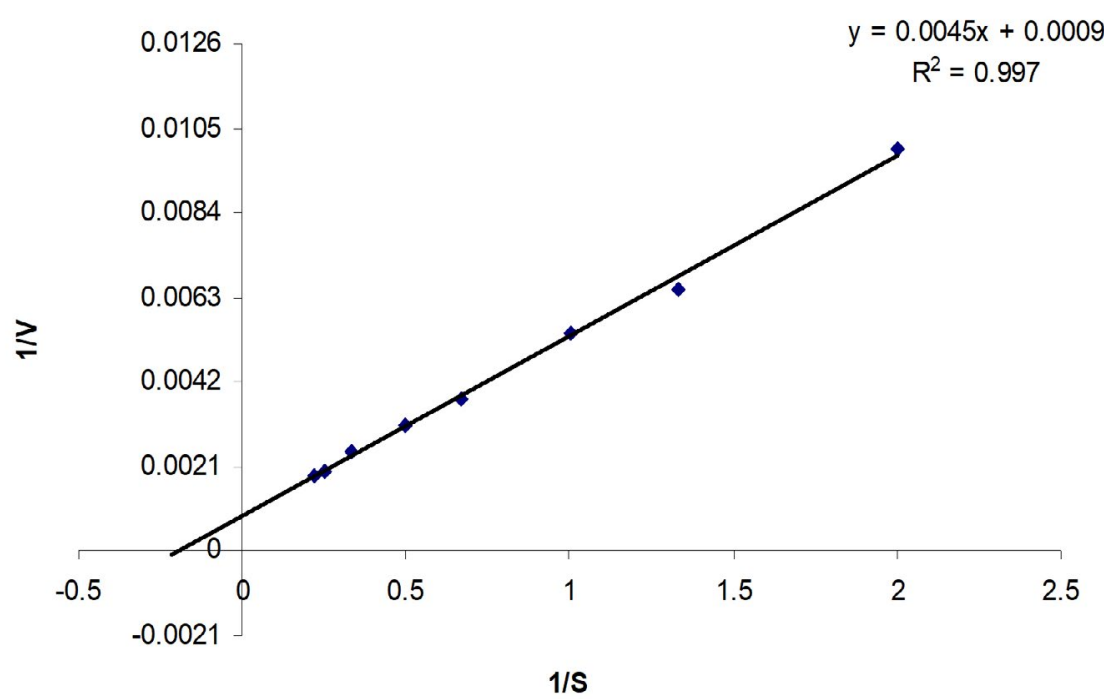

Fig. 4. Reciprocal velocity plot (Lineweaver-Burk's plot) of purified $\beta$-mannanase activity as a function of locust bean gum concentration.

Journal of Pure and Applied Microbiology 
propanol caused almost $70 \%, 20 \%, 80 \%$ inhibition respectively after $1 \mathrm{~h}$ and near complete inhibition after $24 \mathrm{~h}$. Propanone resulted in almost $60 \%$ inhibition after $1 \mathrm{~h}$ and $86 \%$ inhibition was observed after $24 \mathrm{~h}$. Iso-amyl alcohol had a stimulating effect on mannanase activity initially, but prolonged incubation resulted in $28 \%$ inhibitory effect (Table 3). $\beta$-mannanase responded differentially to water-miscible/immiscible solvents ${ }^{26}$, but polar water miscible solvents were found to be more destabilizing for it $^{27}$. As glycerols and polyols have stabilizing effect on the purified enzyme, allowing the use of organic solvents to prevent the enzyme loss during storage. Polyols act by stabilizing hydrophobic interactions that help to maintain native structure and preserve the hydration shell around the protein molecule.

\section{Suitability of $\beta$-mannanase for detergent application}

E numbers are codes for permitted food additives classified by European Food Safety Authority. Heteromannans Locust bean gum and guar gum are two of the most commonly used thickeners, designated by the E-numbers E410 and E412 respectively ${ }^{28}$. Guar gum and locust ban gum are versatile food additive present in instant noodles, pasta, Ice-cream, BBQ Sauce, Mayonnaise, salad dressing, thus generating tough and difficult to remove stains.

Various Food and personal care products which soil the clothes contain these additives, owing to their high molecular weight; they exhibit a strong adherence to fabric. These colorless gums though appear to be removed from clothes in the wash, but as they are strongly adhered to the fabric, particulate arising from wear of the garment or coming from a second wash can bind to garment and reappear as stains. Treatment with $\beta$-mannanase can reduce this reappearing stain phenomenon, can recover paleness and can prevent binding of certain soils to the cellulosic material. Enzymes being highly specific in action, nonspecific hydrolysis of mannan are not carried out by other glycoside hydrolases- amylases and cellulases usually present in detergents as they do not recognize the structure of mannan and cannot therefore remove gum based stains from fabric ${ }^{29,30}$. For an enzyme to be used as detergent additive, it should possess the following characteristics to make it useful as detergent enzyme: Stability - in Broad $\mathrm{pH}$ range, at relatively high temperatures $\left(35-70^{\circ} \mathrm{C}\right)$ and in the presence of certain surfactants and detergent additives with specific substrate specificity.

Effect of surfactants on enzyme activity and stability

$\beta$-mannanase possessing activity in the broad $\mathrm{pH}$ range was recognized as potential detergent additive and part of stain-removing formulations. Taking this into consideration, the effect of various ionic and non-ionic surfactants on mannanase activity was investigated. The $\beta$-mannanase retained significant activity in all the nonionic surfactants viz. Triton-X-100 (TX100), Polysorbate-20 (PS-20) and Polysorbate-40 (PS-40). These non-ionics possess no electrical charge on hydrophilic ends, which makes them averse to interact with $\mathrm{Ca}^{2+}$ and $\mathrm{Mg}^{2+}$ ions in hard

Table 4. Effect of various detergent additives on enzyme stability of purified $\beta$-mannanase from $P$. thiaminolyticus

\begin{tabular}{lll}
\hline Detergent additive & Class & Residual activity (\%) \\
\hline Sorbitol & Builder & $96.9 \pm 2.50$ \\
Mannitol & Builder & $91.48 \pm 1.76$ \\
Zeolite & Builder & $33.67 \pm 2.9$ \\
Citric acid & Builder & $10.52 \pm 1.25$ \\
H2O2 & Bleaching agent & $92.2 \pm 0.25$ \\
Sodium perborate & Bleaching agent & $28.93 \pm 2.67$ \\
PVP & Dye tranfer inhibitor & $95.2 \pm 3.37$ \\
CM-cellulose & Anti redeposition agent & $90.7 \pm 4.67$ \\
PEG & Optical brightener & $124.19 \pm 2.82$ \\
Sodium sulfate & Bulking agent & $89.45 \pm 3.52$ \\
\hline
\end{tabular}

The purified enzyme was incubated at $60^{\circ} \mathrm{C}$ for $1 \mathrm{~h}$ in the presence of different detergent additives and the residual activity was determined 
water making them hard water resistant. They are excellent degreasers extensively used in laundry detergents, and dishwashing liquids ${ }^{31}$. Addition of 0.4 to $1.0 \%(\mathrm{v} / \mathrm{v})$ of the cationic surfactants cetyltrimetylammonium bromide (CTAB) led to total inhibition of mannanase activity. Fig. 5 (a) shows the effect of PS-20, PS-40, TX 100, CTAB and SDS on the activity of mannanase. The effect of surfactants on the enzyme denaturation was examined further by exposing the enzyme to different concentrations of surfactants at different time intervals Fig. 5 (b). Different SDS concentration (1, 0.1 and $0.01 \%)$ led to about $80 \%$ of enzyme activity loss in 15,30 and $60 \mathrm{~min}$ respectively. These findings agreed well with the studies reported earlier. Several enzymes interact with SDS to form enzyme-SDS
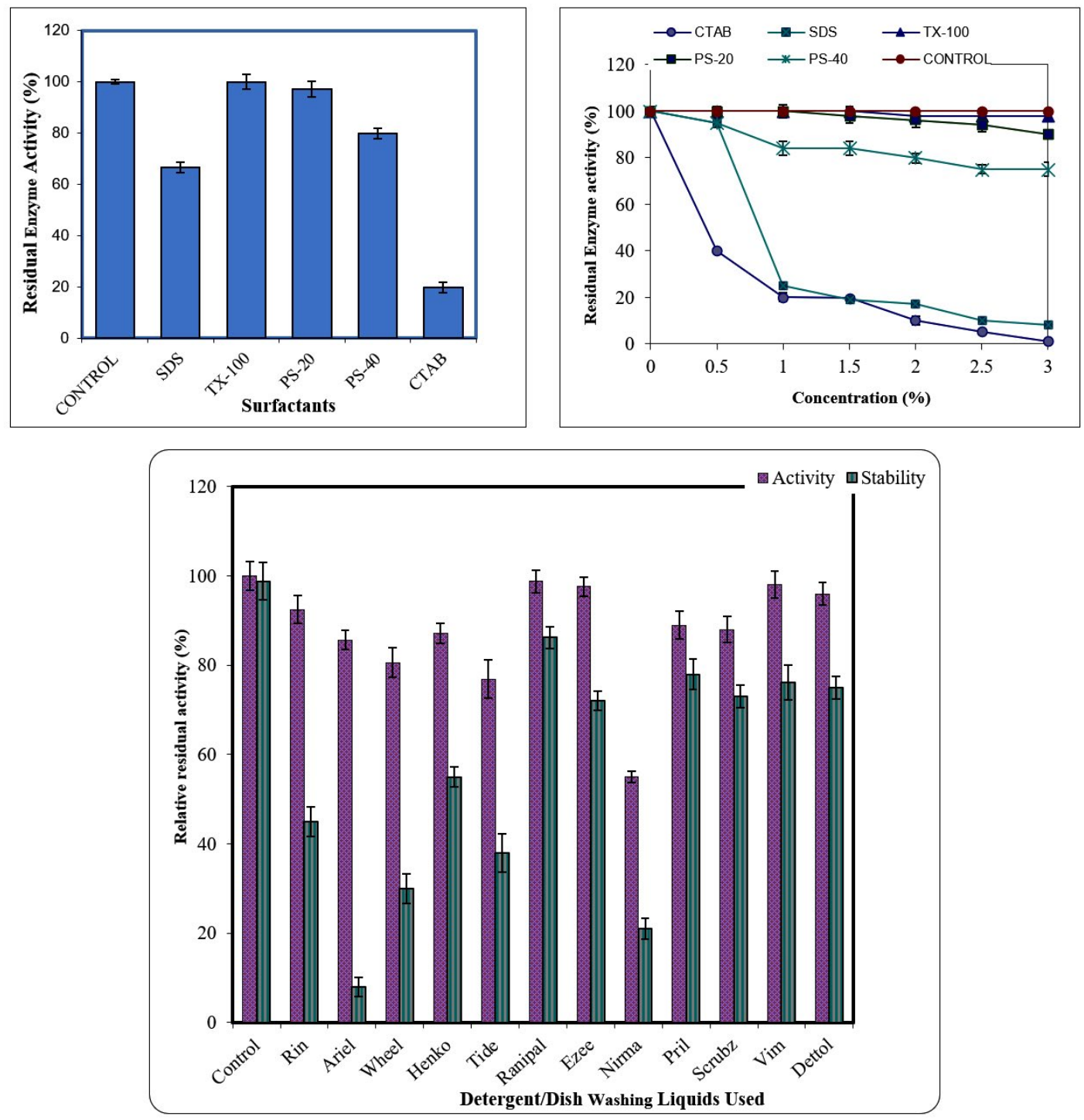

Fig. 5. (a) Effect of various surfactants on enzyme activity of purified $\beta$-mannanase from $P$. thiaminolyticus. (b) Effect of various surfactants on enzyme stability of purified $\beta$-mannanase from $P$. thiaminolyticus. The purified enzyme was incubated at $60^{\circ} \mathrm{C}$ for $1 \mathrm{~h}$ in the presence of different concentration of surfactants and the residual activity was determined. (c) Effect of various detergents/dish washing liquids on enzyme activity and stability of purified $\beta$-mannanase from $P$. thiaminolyticus. The purified enzyme was incubated at $60^{\circ} \mathrm{C}$ for $45 \mathrm{~min}$ in the presence of detergents/dishwashing liquids and enzyme stability (grey bars) was determined. 
complexes. Generally at low concentration, SDS bind the outer surface of the enzyme, perhaps higher SDS concentration induced a larger conformational change leading to unfolding and enzyme inactivation ${ }^{31,32}$. Thus, Inhibitory effect of SDS depends upon its concentration and incubation time for denaturation of mannanase.

\section{Effect of detergent additives}

The $\beta$-mannanase showed significant stability with various detergent additives i.e. builders (sorbitol, mannitol, zeolite and citric acid) and bleaching agents $\left(\mathrm{H}_{2} \mathrm{O}_{2}\right.$, sodium perborate). It also displayed excellent stability along with occurrence of other detergent components like optical brighteners (Polyethylene glycol), antiredeposition agents and soil suspension agents (CM-cellulose), dye tranfer inhibiting agents (Polyvinyl pyrollidone) and bulking agent (Sodium sulfate). (Table 4).

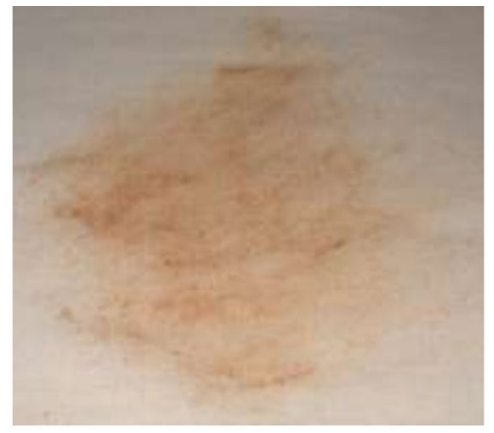

(a)

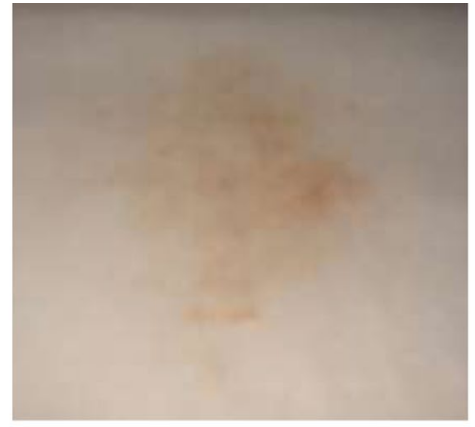

(b)

\section{Compatibility with laundry detergents}

The $P$. thiaminolyticus $\beta$-mannanase showed moderate activity and compatibility along with commercial detergents (Rin, Ariel, Wheel, Tide, Henko, Nirma, Ranipal and Ezee). The mannanase maintained more than $50 \%$ activity after $15 \mathrm{~min}$ incubation at $60^{\circ} \mathrm{C}$ with most of the detergents tested but retained $100 \%$ activity in the presence of Ranipal and Ezee Fig. 5 (c). However on increasing exposure time to detergents $\beta$-mannanase retained less than $10 \%$ activity (data not shown). Thus, to overcome the effect of variable $\mathrm{pH}$ of different washing powders on enzyme stability when the effect of all washing powders (pre adjusted at $\mathrm{pH}$ 7.0) was checked, $\beta$-mannanase retained $55.2 \%, 46.7 \%$ and $38.5 \%$ activity in Henko, Rin and Tide respectively, but less than $30 \%$ in Nirma

Fig. 6. (a) Images of chocolate ice cream spot on cotton cloth. (b) Images of chocolate ice cream spot taken after washing in TX-100 with detergent additives without mannanase and after additional particulate soil treatment. (c) Images of chocolate ice cream spot taken after washing in TX-100 with detergent additives with mannanase and after additional particulate soil treatment.

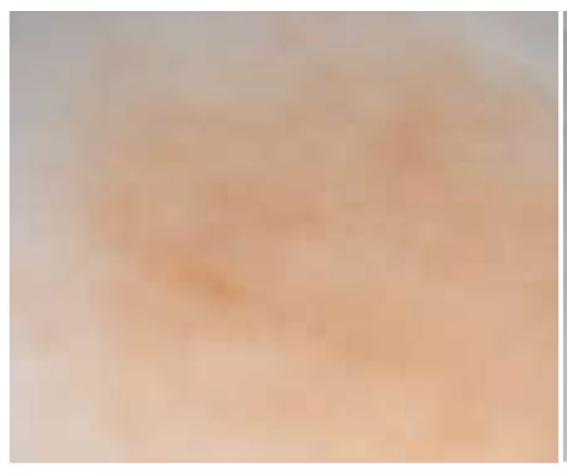

(a)

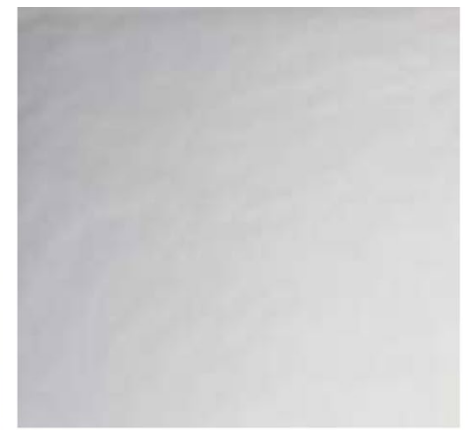

(c)

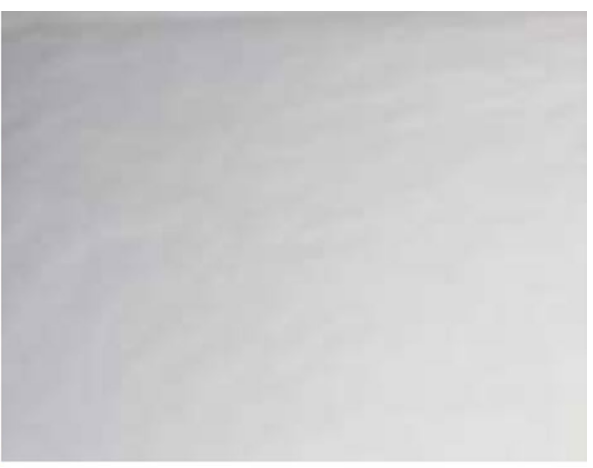

(b)

Fig. 7. Images of anti-redeposition effect of mannanase with tennis court clay on cotton cloth (a) without mannanase (b) with mannanase. 
and Wheel. It was observed that Ariel was very destabilizing for this enzyme, whereas enzyme was $90 \%$ and $72 \%$ stable in Ranipal and Ezee respectively (Fig. 5c). This inhibition of the enzyme activity by different detergents could be due to their ingredients and not by their high alkaline nature ${ }^{33}$. Many detergent additive enzymes possess even lesser activity than this ${ }^{34}$. Srivastava et al., (2014) reported an endo-mannanase from Bacillus sp. CFR1601 showing compatibility with various detergents. Enzyme retained about 89$100 \%$ activity in detergents but at a temperature of $37^{\circ} \mathrm{C}^{6}$. In comparison $\beta$-mannanase from $P$. thiaminolyticus was significantly stable even at a temperature of $60^{\circ} \mathrm{C}$ in commercial detergents. As high temperature washing is preferred aiding to better cleaning.

\section{Compatibility with dish washing liquids}

Various brands of liquid cleansers, dishwashing liquids readily available in local market were evaluated for $\mathrm{pH}$. Real-life situation was simulated by preparing a dilution of each cleanser with tap water and then change in $\mathrm{pH}$ was noted. Most of it was showing wide ranging $\mathrm{pH}$ in the range 4-8 and compatibility with normal skin $\mathrm{pH}$. Without neutralizing the $\mathrm{pH}$ of Dishwashing liquids, $\beta$-mannanase retained about $90 \%$ activity in Vim, Pril, Scrubz and Dettol Kitchen Dish washing Liquids respectively, and more than $70 \%$ even after exposure time of $45 \mathrm{~min}$ at $60^{\circ} \mathrm{C}$ in these dish washing liquids (Fig. $5 \mathrm{c}$ ). So this enzyme could have a potent application as an additive in dishwashing liquids as heteromannans are a component of many BBQ sauces, ketchups and instant foods as thickening agent generating tough and sticky stains. $\beta$-mannanase degraded heteromannan reduced the viscosity of residual food in cooking vessels and dishes thus easing out cleaning of tough stains thereby facilitating wash out of sticky stains (image not shown).

\section{Cleaning performance test}

In order to study the potential of mannanase as detergent additive for laundry, white cotton swatches $(8 \times 8 \mathrm{~cm})$ were stained with chocolate ice cream (Fig. 6 a-c) and salad dressing (image not shown). Stained spots were allowed to dry at room temperature. To check cleaning performance of mannanase, before washing, all the stained swatches were dipped/ immersed in the wash solution (flasks a-f) at $60^{\circ} \mathrm{C}$ for $30 \mathrm{~min}$. the test swatches were rinsed with water twice for $5 \mathrm{~min}$ and then dried for determining the washing performance. Among all the tested detergents/surfactants, TX-100 and PS 20 were most suitable surfactants for enzyme action. Cleaning performance study demonstrated that flasks (c-f) were containing effective wash solutions.

A lot better stain removal effect was easily noticeable when mannanase was added to TX-100 and commercial laundry detergent (Fig. 6c). Enzyme quickly cut the mannan based gums thus hydrolyzing the stain which is easily removable along with wash water. After stain hydrolysis, Mannan gum dirt/soil residues in the wash liquor can act like dirt attracters. Because of their sticking tendency to cellulose fibers can cause redeposition or back stain on other clean fabrics in the wash liquor.

Anti-soil redeposition effect of mannanase was studied by treating cotton swatch with tennis court clay and LBG, it was observed that in the absence of mannanase cotton swatch emerged heavily dirty with tennis court clay (Fig. 7a). When $\beta$-mannanase is present, it cut down gum based polymers quickly suspending and emulsifying into smaller more water soluble oligosaccharides, which do not stick to the fabric and are easily swirled out of the wash and maintaining the whiteness of the fabric and inhibiting redeposition and back stain on otherwise clean cloths (Fig. 7 b). Based on the stability of purified enzyme with different surfactants and commercial detergents, it was observed that the mannanase derived from $P$. thiaminolyticus may get damaged by commercial detergents, perhaps induced by conformational change leading to unfolding and enzyme inactivation ${ }^{31,32}$. Since composition of the commercial detergents was not very clear because none of the label contained the information about the type of surfactants (anionic and nonionic) present, and the type of enzymes used in the composition. Hence it can be concluded that if a detergent composition was specially developed while keeping in mind the present enzyme, better cleaning efficiency can be obtained. For the reason of its extensive thermal stability and compatibility with surfactant and detergent additives, this mannanase could have specialized industrial application as an additive or specifically a rinse aid 
composition for laundry ${ }^{30}$. A specialized cleaning rinse aid composition comprising a detergent ingredient selected from nonionic surfactant; a builder (sorbitol, mannitol, zeolite) and a bleach system with optical brighteners, will fulfill all the requirements mentioned earlier for its application in laundry detergent formulations.

As mannanase in the present study is capable of effectively degrading or hydrolyzing any soiling or spots containing galactomannan, glucomannan and, thus is capable of cleaning dishes comprising such soiling or spots, Moreover, $\beta$ - mannanase from $P$. thiaminolyticus was showing wide-ranging temperature stability in the range of $35-60^{\circ} \mathrm{C}$ for more than $1 \mathrm{~h}$ which is the normal washing time even in automatic dish washers.

The enzyme used in this study was effective at low level, compatible with various detergent components, active at wide range of temperatures and capable of removing stained spots. The surfactant class, enzyme characteristics, and ratio of amalgamating ingredients need to be considered when mixing enzyme with detergent for achieving a better cleaning performance for a particular application ${ }^{33}$.

In conclusion it can be said that this purified mannanase has many desirable characteristics, viz., high thermal activity, stability in broad $\mathrm{pH}$ conditions, high hydrolytic activity towards heteromannans LBG and KGM, no cellulase activity and high specific activity combined with the characteristic of certain metal ion and protease resistance, meet the criteria for this $\beta$-mannanase to be added as an additive for both dishwashing and laundry detergents.

\section{ACKNOWLEDGMENTS}

This manuscript and the research behind it would not have been possible without the exceptional support of my mentor, Dr. Jagdeep Kaur, Professor, Department of Biotechnology, Panjab University, Chandigarh for providing facility for carrying out the work. I deem it a unique privilege to acknowledge and thank administration of Goswami Ganesh Dutta Sanatan Dharma College, Chandigarh for providing the related support to compile this work.

\section{FUNDING}

None.

\section{DATA AVAILABILITY}

All datasets generated or analyzed during this study are included in the manuscript.

\section{ETHICS STATEMENT}

This article does not contain any studies with human participants or animals performed by any of the authors.

\section{REFERENCES}

1. Vanzyl WH, Rose SH, Trollope K, Gorgens JF. Fungal $\beta$-mannanases: Mannan hydrolysis, heterologous production and biotechnological applications. Proc Biochem. 2010;45(8):1203-1213. doi: 10.1016/j. procbio.2010.05.011

2. Dhawan S, Kaur J. Microbial mannanases: An overview of production and applications. Crit Rev Biotechnol. 2007;27(4):197-216. doi: 10.1080/07388550701775919

3. Srivastava PK, Panwar DK, Prashanth VH, Kapoor M. Structural characterization and in vitro fermentation of $\beta$-manno-oligosaccharides produced from locust bean gum by GH-26 endo- $\beta$-1,4-mannanase (ManB1601). J Agric Food Chem. 2017;65(13):2827-2838. doi: 10.1021/acs.jafc.7b00123

4. Phakeenuya V, Ratanakhanokchai K, Kosugi A, Tachaapaikoon C. A novel multifunctional GH9 enzyme from Paenibacillus curdlanolyticus B-6 exhibiting endo/exo functions of cellulase, mannanase and xylanase activities. Appl Microbiol Biotechnol. 2020;104(5):2079-2096. doi: 10.1007/s00253-02010388-3

5. Dhawan S, Singh R, Kaur R, Kaur, J. A $\beta$-mannanase from Paenibacillus sp.: optimization of production and its possible prebiotic potential. Biotechnol Appl Biochem. 2016;63(5):669-678. doi: 10.1002/bab.1419

6. Srivastava PK, Kapoor M. Cost-effective endomannanase from Bacillus sp. CFR1601 and its application in generation of oligosaccharides from guar gum and as detergent additive. Prep Biochem Biotechnol. 2014;44(4):392-417. doi: 10.1080/10826068.2013.833108

7. Fu X, Huang X, Liu P, et al. Cloning and Characterization of a Novel Mannanase from Paenibacillus sp. BME-14. J Microbiol Biotechnol. 2010;20(3):518-524.

8. Chandra MRS, Lee YS, Park IH, Zhou Y, Kim KK, Choi YL. Isolation, Purification and Characterization of a Thermostable $\beta$-Mannanase from Paenibacillus sp. DZ3. J Korean Soc Appl Biol Chem. 2011;54(3):325-331. doi: 10.3839/jksabc.2011.052

9. Zhang JX, Chen ZT, Meng XL, et al. Gene cloning, expression and characterization of a novel $\beta$-mannanase from the endophyte Paenibacillus sp. CH-3. Biotechnol. Appl Biochem. 2017;64(4):471-481. doi: $10.1002 /$ bab. 1510 
10. Miller GL. Use of dinitrosalicylic acid reagent for determination of reducing sugar. Anal Chem. 1959;31(3):426-428. doi: 10.1021/ac60147a030

11. Blank K, Sugiyama RH, Dekker CA. Activity staining of nucleolytic enzymes after sodium dodecyl sulfatepolyacrylamide gel electrophoresis: use of aqueous iso-propanol to remove detergent from gels. Anal Biochem. 1982;120(2):267-275. doi: 10.1016/00032697(82)90347-5

12. Beguin P. Detection of cellulase activity in polyacrylamide gels using Congo red-stained agar replicas. Anal Biochem. 1983:131:333-336. doi: 10.1016/0003-2697(83)90178-1

13. Ma $Y, X u e Y$, Dou $Y, X u Z$, Tao W, Zhou P. Characterization and gene cloning of a novel $\beta$-mannanase from alkaliphilic Bacillus sp. N16-5. Extremophiles. 2004;8(6):447-454. doi: 10.1007/s00792-004-0405-4

14. Yang $P$, Li $Y$, Wang $Y$, et al. A novel $\beta$-mannanase with high specific activity from Bacillus circulans CGMCC1554: gene cloning, expression and enzymatic characterization. Appl Biochem Biotechnol. 2009;159(1):85-94. doi: 10.1007/s12010-008-8364-3

15. Gibbs MD, Reeves RA, Sunna A, Bergquist PL. Sequencing and expression of a $\beta$-mannanase gene from the extreme thermophile Dictyoglomus thermophilum Rt46B.1, and characteristics of the recombinant enzyme. Curr Microbiol. 1999;39(6):351357. doi: $10.1007 / \mathrm{s} 002849900471$

16. Cheng L, Duan S, Feng $X$, Zheng K, Yang Q, Liu, Z. Purification and characterization of a thermostable $\beta$-mannanase from Bacillus subtilis BE-91: potential application in inflammatory diseases. BioMed Res. Inter. 2016;2016:6380147. doi: 10.1155/2016/6380147

17. Jiang Z, Wei Y, Li D, Li L, Chai P, Kusakabe I. Highlevel production, purification and characterization of a thermostable $\beta$-mannanases from the newly isolated Bacillus subtilis WY 34. Carbohydr. Polym. 2006;66(1):88-96. doi: 10.1016/j.carbpol.2006.02.030

18. Duffaud GD, McCutchen CM, Leduc P, Parker KN, Kelly, RM. Purification and characterization of extremely thermostable $\beta$-mannanase, $\beta$-mannosidase, and $\alpha$-galactosidase from the hyperthermophilic eubacterium Thermotoga neopolitana 5068. Appl Environ Microbiol. 1997;63(1):169-177. doi: 10.1128/ AEM.63.1.169-177.1997

19. Politz O, Krah M, Thomsen KK, Borriss RR. A highly thermostable endo-1, 4-beta-mannanase from the marine bacterium Rhodothermus marinus. Appl Microbiol Biotechnol. 2000;53(6):715-721. doi: 10.1007/s002530000351

20. Zhang W, Liu Z, Zhou S, Mou H, Zhang R. Cloning and expression of a $\beta$-mannanase gene from Bacillus sp. MK-2 and its directed evolution by random mutagenesis. Enz MicrobTechnol. 2019;124:70-78. doi: 10.1016/j.enzmictec.2019.02.003

21. Hatada Y, Takeda N, Hirasawa K, et al. Sequence of the gene for a high-alkaline mannanase from an alkaliphilic
Bacillus sp. strain JAMB-750, its expression in B. subtilis and characterization of the recombinant enzyme. Extremophiles. 2005;9(6):497-500. doi: 10.1007/ s00792-005-0460-5

22. Seesom $\mathrm{W}$, Thongket $\mathrm{P}$, Yamamoto $\mathrm{T}$, Takenaka $S$, Sakamoto T, Sukhumsirichart W. Purification, characterization, and overexpression of an endo-1, 4- $\beta$-mannanase from thermotolerant Bacillus sp. SWU60. World J Microbiol Biotechnol. 2017;33(3):53. doi: 10.1007/s11274-017-2224-7

23. Cui F, Shi J, Lu Z. Production of neutral beta-mannanase by Bacillus subtilis and its properties. Wei Sheng Wu Xue Bao. 1999;39(1):60-63.

24. Yang JK, Chen QC, Zhou B, Wang XJ, Liu SQ. Mannooligosaccharide preparation by the hydrolysis of konjac flour with a thermostable endo-mannanase from Talaromyces cellulolyticus. J Appl Microbiol. 2019;127(2):520-532. doi: 10.1111/jam.14327

25. Sun YM, Yu HY, Wang WJ, Yang YS, Yang YH. Purification and properties of Bacillus subtilis SA-22 endo-1, 4-beta-D-mannanase. Sheng Wu Gong Cheng Xue Bao. 2003;19(3):327-330.

26. Bovora C, Carrea G, Ottolina G, Riva S. Effects of water activity on $\mathrm{V}_{\max }$ and $\mathrm{K}_{\mathrm{m}}$ of lipase catalyzed transesterification in organic media. Biotech Lett. 1993;15 (9):937-942. doi: 10.1007/BF00131760

27. Klibanov AM. Asymmetric enzymatic oxidoreductions in organic solvents. Curr Opin Biotechnol. 2003;14(4):427-431. doi: 10.1016/S09581669(03)00074-0

28. Mortensen FA, Aguilar R, Crebelli A, Domenico D, Frutos MJ et al. Re-evaluation of guar gum (E 412) as a food additive. EFSA Journal. 2017;15(2):e04669. doi: 10.2903/j.efsa.2017.4669

29. Smulders E. Laundry detergents. Wiley Online Library, Weinheim. 2002. doi: 10.1002/3527600450

30. McCoy M. An update on the latest developments within the detergent industry, also introducing the latest new detergent enzyme: a mannanase. Chem Eng News. 2001;20:19-32.

31. Hauthal H. Types and Typical Ingredients of Detergents. In Handbook Of Detergents, Part C; CRC Press: Boca Raton, FL, USA. 2004:1-99.

32. Otzen DE. Protein unfolding in detergents: effect of micelle structure, ionic strength, $\mathrm{pH}$, and temperature. Biophys J. 2002;83(4):2219-2230. doi: 10.1016/S00063495(02)73982-9

33. Stoner MR, Dale DA, Gualfetti PJ, Becker T, Randolph TW. $\mathrm{Ca}^{2+}$ surfactant interactions affect enzyme stability in detergent solutions. Biotechnol Prog. 2005;21(6):1716-1723. doi: 10.1021/bp050149k

34. Bhosale SH, Rao MB, Deshpande VV, Srinivasan MC. Thermostability of high-activity alkaline protease from Conidiobolus coronatus (NCL 86.8.20). Enz Microb Technol. 1995;17(2):136-139. doi: 10.1016/01410229(94)00045-S 